\title{
Absorción acústica de espumas de aluminio
}

\section{Acoustic properties of aluminium foams}

\author{
M. A. Navacerrada(*), C. Díaz ${ }^{(*)}$, A. Pedrero(*) y L. E. García(*)
}

Recepción/Received: 4-XII-06

Aceptación/Accepted: 28-VI-07

Publicado online/Online publishing: 20-VI-08

\section{RESUMEN}

Se presenta un estudio del coeficiente de absorción acústica a incidencia normal de espumas de aluminio fabricadas mediante la técnica pulvimetalúrgica. Se fabricaron espumas de aluminio de distinta morfología superficial variando el tipo de precursor y usando materiales de relleno durante el proceso de espumación. Se muestra un estudio comparativo del coeficiente de absorción acústica de las espumas de aluminio fabricadas y las espumas comerciales conocidas como ALPORAS. Para cada muestra fabricada se estudió la influencia del espesor sobre el valor del coeficiente de absorción.

El atractivo de las espumas de aluminio radica en que en ellas se combinan interesantes propiedades acústicas y mecánicas. Se analizó el efecto de una cámara de aire de 2,5 y $10 \mathrm{~cm}$ de anchura sobre el coeficiente de absorción acústica, solución constructiva habitual para reducir el tiempo de reverberación en un recinto. Los resultados muestran que se consigue un aumento significativo del valor del coeficiente de absorción a bajas frecuencias. Este aumento depende de la densidad y espesor de la espuma de aluminio y de la anchura de la cámara de aire. En esta misma línea, y dado el uso habitual de lanas minerales como absorbentes acústicos también se investigó el coeficiente de absorción a incidencia normal de la espuma de aluminio con una lana mineral.

Palabras clave: absorbentes acústicos, coeficiente de absorción, tubo de impedancia.

\section{SUMMARY}

The article discusses normal incidence sound absorption by aluminium foam manufactured with powder metallurgy technology. Aluminium foams with different surface morphologies were obtained by varying the type of precursor and adding filler materials during the foaming process. The sound absorption coefficients found for these aluminium foams were compared to the coefficient for commercial foams marketed under the name ALPORAS. The effect of foam thickness on the absorption coefficient was studied for each sample prepared.

The combination of good acoustic and mechanical properties makes aluminium foams particularly attractive products. The study included an analysis of the effect of 2-, 5- and 10-cm air gaps on the sound absorption coefficient. The results showed that such gaps, which are routinely used in construction to reduce the reverberation period in indoor premises, raised the low frequency absorption coefficient significantly. This increase was found to depend on aluminium foam density and thickness and the depth of the air gap. In this same line, we have investigated the absorption coefficient of the aluminium foams combined with a mineral fiber panel.

Keywords: sound absorbers, absorption coefficient, impedance tube.

(*) Universidad Politécnica de Madrid, (Madrid, España). 


\section{INTRODUCCIÓN}

Los materiales celulares son una nueva y atractiva clase de materiales que ofrecen una gran variedad de aplicaciones estructurales y funcionales. Las espumas metálicas son un tipo particular de estos materiales y con dicho término se hace referencia a todos aquellos materiales metálicos con algún tipo de porosidad. Entre los diferentes métodos empleados para la fabricación de las espumas metálicas destacan aquellos en los que la estructura se genera mediante la adición de un agente espumante al baño del metal fundido, o bien mediante la espumación de precursores sólidos que ya contienen cantidades del agente espumante (1-2).

En las espumas metálicas junto con su bajo peso específico se combinan una serie de propiedades mecánicas, térmicas y acústicas que las hace muy atractivas para diversas aplicaciones en la industria automovilística, biomecánica o en el sector de la construcción (1-3). No obstante, son la naturaleza de la matriz y la densidad de la espuma metálica los parámetros que definen las propiedades del material. Por ello, aunque se han fabricado espumas metálicas de titanio, cobre, magnesio y acero, debido a su resistencia a la corrosión y bajo punto de fusión la más ampliamente estudiada es la fabricada a partir del aluminio y sus aleaciones.

Entre las propiedades específicas que presentan las espumas de aluminio destacan su gran capacidad de deformación frente a una carga constante, su resistencia al fuego y en general, por su estructura de cavidades también presentan un alto nivel de absorción acústica para el rango de frecuencias comprendido entre 1000 y $5000 \mathrm{~Hz}$ (4). Como soluciones para el control del ruido se usan comúnmente materiales porosos (5-6), siendo muy habituales los materiales fibrosos y las espumas poliméricas. En este línea, existe un interés creciente en el uso de las espumas de aluminio como absorbentes acústicos sobre todo en ambientes adversos puesto que son resistentes a la meteorología, no tóxicas y fáciles de limpiar.

Este trabajo se centra en el estudio de la absorción acústica de espumas de aluminio fabricadas mediante la espumación por tratamiento térmico de precursores obtenidos mediante la técnica pulvimetarlúrgica (7-8). Esta técnica fue desarrollada y patentada por el Instituto Fraunhofer de Bremen en Alemania en 1992 (9). La producción de espumas de aluminio mediante esta técnica es especialmente atractiva por su facilidad para producir piezas con distintas formas a costos razonablemente bajos. Variando la aleación utilizada y las condiciones de fabricación se han conseguido espumas de aluminio de diferente morfología superficial. Para cada muestra fabricada se presenta un estudio del coeficiente de absorción

\section{INTRODUCTION}

Cellular materials constitute a new and attractive class of products with a wide variety of structural and functional applications. Metallic foams, a term that encompasses all porous metallic materials, are a specific type of such products. Foremost among the methods used to produce metallic foams are those in which the structure is generated by adding a foaming agent to the molten metal or by foaming solid precursors that contain certain amounts of foaming agent (1-2).

In addition to their low specific weight, metallic foams feature a series of mechanical, thermal and acoustic properties that make them particularly well suited applications in the automotive, biomechanical and construction industries (1-3). In this regard, the nature of the metal itself and the density of the metallic foam are the parameters that define the properties of the end product. While metallic foams have been made from titanium, copper, magnesium and steel for their high corrosion resistance and low melting points, the material that has been most widely studied in this context is aluminium and its alloys.

The specific properties that characterize aluminium foams include their deformability under constant loads, fire resistance and in general, as a result of the structure of their cavities, their excellent sound absorption for frequencies ranging from 1000 to $5000 \mathrm{~Hz}$ (4). As a general rule, noise control solutions deploy porous materials (56), usually fibrous products and polymeric foams. In this vein, a growing interest has been observed in the use of aluminium foams as sound absorbers, particularly in adverse environments, where their weather-resistance, non-toxicity and ease of cleaning enhance performance.

This study focused on an analysis of sound absorption by aluminium foams manufactured by heating precursors produced with the powder metallurgy technology (7-8) developed and patented by the Fraunhofer Institute at Bremen, Germany, in 1992 (9). The manufacture of aluminium foams with this technique is particularly appealing because articles of different shapes can be obtained at reasonably low production costs. Aluminium foams with different surface morphologies were prepared by varying the alloy used and the processing conditions. The effect of thickness on the normal incidence absorption coefficient was found for each sample made. The absorption coefficient for the foams prepared was compared to 
a incidencia normal en función del espesor. Se ha realizado un estudio comparativo del coeficiente de absorción de las espumas fabricadas con las espumas de aluminio comerciales llamadas ALPORAS.

Uno de los principales objetivos de este trabajo ha sido estudiar las posibilidades de uso de estas espumas de aluminio como una alternativa a los paneles perforados. Por ello para espesores pequeños en los que algunas cavidades o poros de su estructura atraviesan la lámina de espuma se ha caracterizado el efecto sobre el coeficiente de absorción de una cámara de aire de varios espesores. También se ha caracterizado el coeficiente de absorción de la estructura consistente en una espuma de aluminio y una placa de lana mineral.

\section{PROGRAMA EXPERIMENTAL}

\subsection{Materiales}

Las muestras fueron fabricadas en el Departamento de Ingeniería de Materiales de la Escuela Técnica Superior de Minas de la Universidad Politécnica de Madrid. En la fabricación se parte de una mezcla de polvos de la aleación de aluminio y de un agente espumante, hidruro de titanio ( $\mathrm{TiH} 2$ ) o mármol. A continuación la mezcla de polvos se compacta isostáticamente en frío y posteriormente es extruida en caliente para obtener el precursor de la espuma en forma de barras cilíndricas o tubos. En estas condiciones la presión resulta suficientemente alta como para evitar la descomposición del $\mathrm{TiH} 2$ antes de poder alcanzar la temperatura de fusión del aluminio. Los tubos del precursor se colocan en un molde hueco cilíndrico de $60 \mathrm{~mm}$ de longitud y $29 \mathrm{~mm}$ de diámetro y el conjunto molde-precursor se introduce en un horno precalentado a $750^{\circ} \mathrm{C}$. Dentro del molde, el agente espumante se descompone liberando gas y forzando al aluminio fundido a expandirse, generándose así la estructura celular. El tiempo requerido para la completa expansión del metal en el seno del molde cerrado oscila entre unos pocos segundos y varios minutos. La densidad de la espuma de aluminio puede ser controlada ajustando parámetros como la concentración del agente espumante, temperatura y velocidad de calentamiento. El diámetro escogido para el molde es el adecuado para el estudio del coeficiente de absorción a incidencia normal en el tubo de impedancia o tubo de Kundt (10).

La muestras así fabricadas se separan del molde cilíndrico y se cortan transversalmente en muestras de igual composición, similar morfología superficial pero distinto espesor. Las espumas de aluminio fueron cortadas en muestras con espesores de 5, 10, 20 y $40 \mathrm{~mm}$. En la Tabla I se indican algunas de las características de las espumas de aluminio fabricadas. Se utilizó diferente the coefficient for ALPORAS, a commercially available aluminium foam.

One of the main objectives of this study was to analyze the feasibility of using such aluminium foams as an alternative to perforated panels. To this end, the effect on the absorption coefficient of air gaps of different depths was studied for thin panels in which some of the cavities or pores were completely open. The absorption coefficients for aluminium foam and mineral wool were likewise compared.

\section{EXPERIMENTAL PROGRAMME}

\subsection{Materials}

The samples were prepared at the Department of Materials Engineering, School of Mining Engineering, Polytechnic University of Madrid. The raw material used was a blend of powdered aluminium alloy and one of two foaming agents, titanium hydride ( $\mathrm{TiH} 2)$ or marble. This blend was compacted by cold isostatic pressing and then hot-extruded to obtain cylindrical or tube-shaped foam precursors. The pressure was kept sufficiently high to prevent decomposition of the $\mathrm{TiH} 2$ before the aluminium melted. The precursor tubes were placed in a hollow cylindrical mould measuring $60 \mathrm{~mm}$ long by $29 \mathrm{~mm}$ in diameter and then heated in an oven at $750^{\circ} \mathrm{C}$. The gas released as the foaming agent in the mould decomposed forced the molten aluminium to expand, generating a cellular structure. The time required for full expansion of the material inside the closed mould ranged from a few seconds to several minutes. The density of the aluminium foam was controlled by adjusting parameters such as foaming agent concentration, temperature and heating rate. The mould diameter chosen was appropriate for the study of the normal incidence absorption coefficient in an impedance or Kundt's tube (10).

After removal from the cylindrical mould the foam was sliced into samples with identical composition and similar surface morphology but different thicknesses: 5, 10, 20 and $40 \mathrm{~mm}$. Table 1 lists some of the characteristics of the aluminium foams prepared. Different foaming agents were used for foams E1 and E2, which led to different pore diameters. Foam E3 was made from the same pre- 
Tabla 1 / Table 1

Propiedades de las espumas de aluminio fabricadas

Properties of processed aluminium foams

\begin{tabular}{|c|c|c|c|c|}
\hline $\begin{array}{l}\text { Espuma de aluminio } \\
\text { Aluminium foam }\end{array}$ & $\begin{array}{l}\text { Composición } \\
\text { Composition }\end{array}$ & $\begin{array}{c}\text { Densidad / Density } \\
\left(\times 10^{3} \mathrm{~kg} / \mathrm{m}^{3}\right)\end{array}$ & $\begin{array}{l}\text { Diámetro de poro } \\
\text { Pore diameter }\end{array}$ & $\begin{array}{l}\text { Estructura celular } \\
\text { Cellular structure }\end{array}$ \\
\hline $\begin{array}{c}\text { Espuma } 1(\mathrm{E} 1) \\
\text { Foam } 1\end{array}$ & $\begin{array}{l}\text { AlSi12+10SiC+Mármol } \\
\text { AlSi12+10SiC+Marble }\end{array}$ & $0,99-1,06$ & $<1 \mathrm{~mm}$ & Uniforme / Uniform \\
\hline $\begin{array}{l}\text { Espuma } 2 \text { (E2) } \\
\text { Foam } 2\end{array}$ & AlSi10+TiH & $0,8-1$ & $<2 \mathrm{~mm}$ & Uniforme / Uniform \\
\hline $\begin{array}{c}\text { Espuma } 3 \text { (E3) } \\
\text { Foam } 3\end{array}$ & AlSi10+ $\mathrm{TiH}_{2}$ & $0,56-0,6$ & $<2 \mathrm{~mm} / 7 \mathrm{~mm} *$ & $\begin{array}{l}\text { Heterogénea / } \\
\text { Heterogeneous }\end{array}$ \\
\hline $\begin{array}{l}\text { Espuma } 4 \text { (E4) } \\
\text { Foam } 4\end{array}$ & AlSi12+TiH & $0,62-0,69$ & $>5 \mathrm{~mm}$ & $\begin{array}{l}\text { Heterogénea / } \\
\text { Heterogeneous }\end{array}$ \\
\hline ALPORAS & & $0,33-0,34$ & $2-4 \mathrm{~mm}$ & Uniforme / Uniform \\
\hline
\end{tabular}

* Diámetro perforaciones cilíndricas / Cylindrical cell diameter

agente espumante para las espumas E1 y E2 lo que dio como resultado diferente diámetro de poro. La espuma E3 se fabricó a partir del mismo precursor que la espuma E2 pero se colocaron tubos de grafito en el molde para conseguir perforaciones cilíndricas en la espuma de aproximadamente $7 \mathrm{~mm}$ de diámetro. En el caso de la espuma E4 además de con tubos de precursor el molde se rellenó con virutas de aluminio de menos de $3 \mathrm{~mm}$ de diámetro.

En la Foto 1 se muestran las espumas de aluminio fabricadas mediante la técnica pulvimetalúrgica y la comercial ALPORAS utilizada en el trabajo como espuma de referencia. cursor as foam E2 but graphite filaments were placed in the mould to obtain cylindrical perforations in the foam approximately $7 \mathrm{~mm}$ in diameter. In the case of foam E4, aluminium shavings less than $3 \mathrm{~mm}$ in diameter were added to the mould along with the precursor tubes.
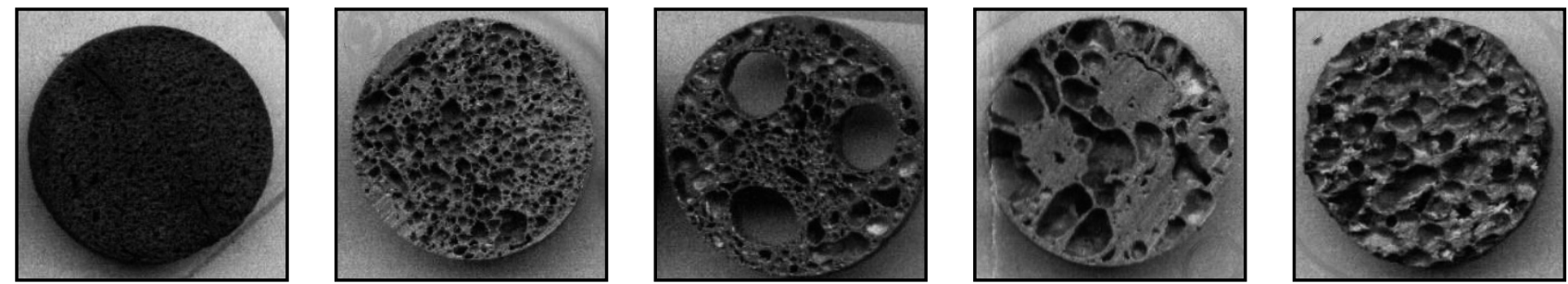

Foto 1. Espumas de aluminio, de izquierda a derecha: E1, E2, E3, E4 y ALPORAS.

Photo 1. Aluminium foams E1,E2, E3, E4 and ALPORAS (from left to right).

\subsection{Medida del coeficiente de absorción acústica a incidencia normal}

El coeficiente de absorción acústica de un material o de un dispositivo absorbente depende de la frecuencia, del ángulo de incidencia del sonido y varía de forma importante según su montaje o instalación. El coeficiente de absorción se mide en cámara reverberante para campo difuso. La medida en el tubo de impedancia o tubo de Kundt (11) es más rápida y se utiliza sobre todo en el proceso de diseño de un material como es el caso del trabajo que se presenta.

\subsection{Measuring the normal incidence sound absorption coefficient}

The sound absorption coefficient of an absorbent material or structure depends on the frequency and angle of incidence of the sound and varies widely with assembly or installation conditions. The absorption coefficient is measured in a reverberation room with a diffuse sound field. Measurement in an impedance or Kundt's tube (11) is quicker and used especially in material design stages, such as in the present study. 
El coeficiente de absorción sonora a incidencia normal de las espumas de aluminio se midió en un tubo de impedancia Modelo 4206 con dos micrófonos Modelo 4186 de B\&K. Se usó un analizador Pulse 3560 C para procesar la señal utilizando la aplicación Material Testing. Para generar la señal en el tubo de impedancia se utilizó el analizador Pulse y un amplificador Pioneer A-305 R.

Para la medida del coeficiente de absorción las muestras deben prepararse con el diámetro exacto del tubo para no dejar cámaras de aire que pueden alterar la medida (12-13). El montaje de la muestra es un factor crítico. En estos primeros ensayos, dada la mayor dificultad para fabricar muestras de $100 \mathrm{~mm}$ de diámetro, nos hemos limitado a estudiar el rango de frecuencias comprendido entre 200 y $6400 \mathrm{~Hz}$. Todos los ensayos se repitieron en dos fechas diferentes para comprobar su reproducibilidad. Por otro lado, los resultados de las medidas realizadas con las espumas ALPORAS están de acuerdo con los publicados ya en la literatura (4).

\section{RESULTADOS Y DISCUSIÓN}

\subsection{Coeficiente de absorción acústica a incidencia normal en función del espesor}

Se midió el coeficiente de absorción a incidencia normal de espumas de aluminio E1, E2, E3, E4 y ALPORAS de 5, 10,20 y $40 \mathrm{~mm}$ de espesor. En la Figura 1 se muestran algunos ejemplos representativos de las curvas medidas. Para cada una de las espumas, se muestra la curva medida para un determinado espesor.
The normal incidence sound absorption coefficient for the aluminium foam was measured in a model 4206 impedance tube with two B\&K model 4186 microphones. A Pulse $3560 C$ analyzer was used to process the signal with Material Testing software. The signal was generated in the impedance tube with a Pulse analyzer and a Pioneer A-305 $R$ amplifier.

The samples had to have the same diameter as the tube for accurate absorption coefficient measurements, to prevent the formation of air gaps that might alter readings (12-13). Sample assembly is a critical factor. In these initial tests, given the greater difficulty involved in preparing 100-mm diameter samples, the range of frequencies studied was limited to 200 to $6400 \mathrm{~Hz}$. All tests were repeated on two different dates to verify reproducibility. The findings for the ALPORAS foams concurred with the data published in the literature (4).

\section{RESULTS AND DISCUSSION}

\subsection{Variation in the normal incidence sound absorption coefficient with thickness}

The normal incidence absorption coefficient was measured in 5-, 10-, 20- and 40-mm thick samples of aluminium foams E1, E2, E3, E4 and the ALPORAS product. Figure 1 shows some representative examples of the curves plotted, one for each foam.

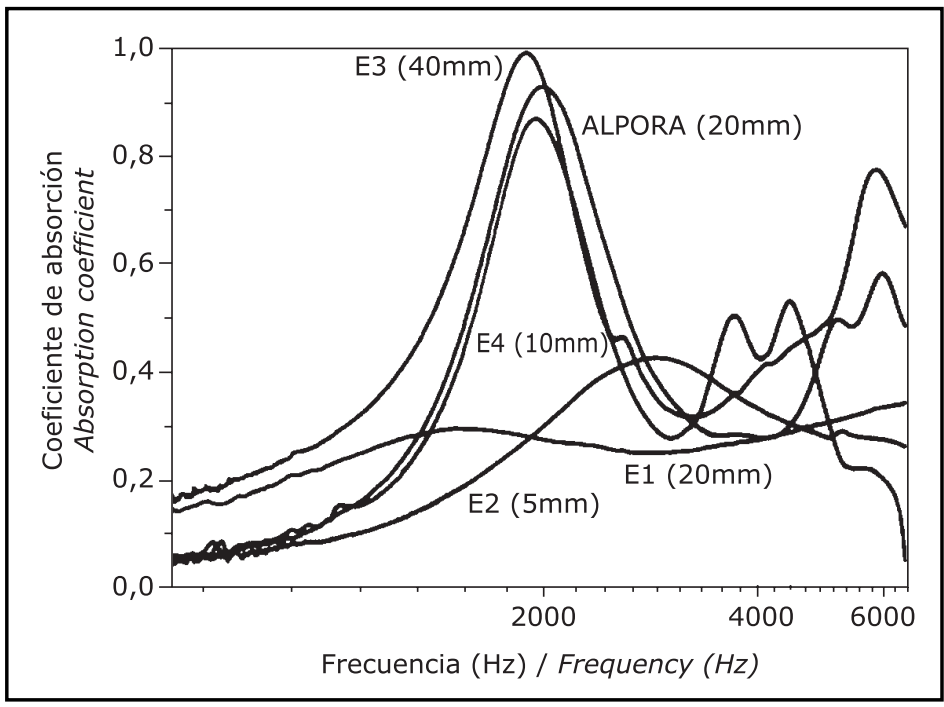

Figura 1. Coeficiente de absorción a incidencia normal para algunos espesores de las espumas de aluminio fabricadas mediante la técnica pulvimetalúrgica y la comercial ALPORAS.

Figure 1. Normal incidence absorption coefficient for selected thicknesses of aluminium foams manufactured with powder metallurgy technology and a commercial foam (ALPORAS). 
Como puede apreciarse en la Figura 1, la característica común a todas las curvas del coeficiente de absorción a incidencia normal es la presencia de un máximo de absorción. A partir de ahora, para realizar un análisis comparativo sencillo tomaremos como referencia el valor del coeficiente de absorción en este máximo y lo denotaremos por $\alpha_{M}$. En la Figura 2 se ha representado para todos los espesores el valor de $\alpha_{M}$ así como el valor de su frecuencia central $f c$.

En la Figura 2 (a) se pueden apreciar dos comportamientos: el de las espumas E1 y E2 en las que $\alpha_{M}$ aumenta cuando su espesor se reduce y el de las espumas E3 y E4 en las que $\alpha_{M}$ disminuye al hacerlo su espesor. Las dos primeras, E1 y E2 de alta densidad y diámetro de poro comprendido entre 1 y $2 \mathrm{~mm}$ no muestran una absorción significativa para espesores superiores a 20 $\mathrm{mm}$. Sin embargo, para estos espesores las espumas E3 y E4 presentan un valor de $\alpha_{M}$ comparable al de las espumas ALPORAS.

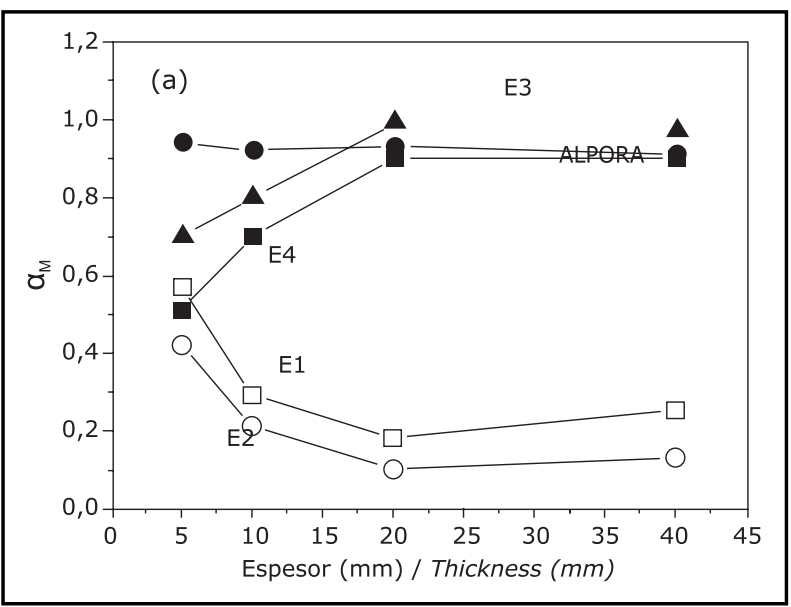

The characteristic common to all these normal incidence absorption coefficient curves is the presence of an absorption peak. This peak absorption coefficient, symbolized as $\alpha_{M}$, was taken in this study as the reference value for simple comparative analysis. The peak absorption coefficient, $\alpha_{M}$, and the central frequency (fc) are plotted against thicknesses in Figure 2.

Two types of behaviour are visible in Figure 2 (a): exhibited by $E 1$ and E2, in which $\alpha_{M}$ increased as the thickness declines and foams E3 and E4, in which $\alpha_{M}$ declined with thickness. The former two, E1 and E2 with high densities and pore diameters between 1 and $2 \mathrm{~mm}$, showed no significant absorption for thicknesses of over $20 \mathrm{~mm}$. By contrast, at these thicknesses foams E3 and E4 had $\alpha_{M}$ values comparable to those for the ALPORAS foam.

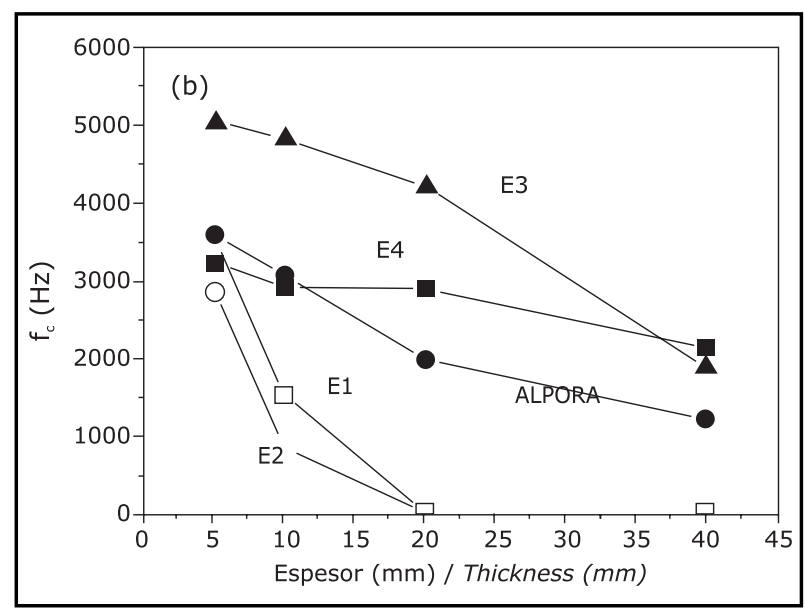

Figura 2. (a) Coeficiente de absorción máximo a incidencia normal $\alpha_{M}$ y (b) frecuencia central, $F c$ del máximo de absorción para espesores de 5, 10, 20 y $40 \mathrm{~mm}$ de todas las espumas fabricadas.

Figure 2. (a) Peak value of the normal incidence absorption coefficient, $\alpha_{M}$, and (b) central frequency, $F c$, at peak absorption for 5-, 10-, 20- and 40-mm foams.

De estos primeros resultados se deduce que el coeficiente de absorción acústica a incidencia normal de las espumas de aluminio está gobernado fundamentalmente por tres parámetros: su espesor, la morfología de los poros o cavidades y su densidad. Cuando la onda sonora penetra en el material, la amplitud de la vibración de las moléculas de aire es amortiguada progresivamente debido a la fricción con las superficies de las cavidades. Las espumas E3 y E4 de menor densidad poseen canales o cavidades, la primera a lo largo de todo el espesor de la muestra generados por los tubos de grafito y la segunda cavidades cerradas cuya longitud oscila entre 8 y $14 \mathrm{~mm}$. Normalmente al disminuir el espesor del material también disminuye la absorción que se produce. Sin embargo no
The deduction drawn from these initial results is that the normal incidence sound absorption coefficient for aluminium foams is governed by essentially three parameters: thickness, pore or cavity morphology and density. When the sound wave penetrates the material, the amplitude of the air molecule vibrations is progressively dampened due to the friction between the molecules and the cavity surfaces. The channels or cavities in low density foam E3, generated by the graphite filaments, were open across the entire thickness of the sample, whereas in E4, likewise a low density foam, they were closed and ranged in length from 8 to $14 \mathrm{~mm}$. Normally, absorption declines with the thickness of the material. Nonetheless, this is not believed to be the reason for the decreasing $\alpha_{M}$ 
pensamos que esta sea la razón por la que se reduce el valor de $\alpha_{M}$ en E3 y E4. Cuando estas espumas se cortan para obtener las muestras de 5 y $10 \mathrm{~mm}$ de espesor algunas cavidades también son cortadas y aunque atraviesan toda la muestra, su longitud o profundidad original se reduce. Se reduce la longitud del canal, el camino recorrido por la onda sonora en el interior del material y por tanto, la fricción.

Aunque es necesario un estudio detallado para explicar el comportamiento del coeficiente de absorción a incidencia normal de las espumas, de estas primeras medidas podemos extraer algunas conclusiones cualitativas. No hay diferencias apreciables entre las espumas debidas al agente espumante ( $\mathrm{TiH}_{2}$ o mármol) usado en la fabricación del precursor. Para tender a conseguir un comportamiento comparable al de las espumas ALPORAS se debe tender a fabricar mediante la técnica pulvimetalúrgica espumas de menor densidad aumentando por ejemplo la cantidad de agente espumante en el precursor. Para espesores por debajo de $10 \mathrm{~mm}$ el valor de $\alpha_{M}$ de todas las espumas de aluminio es comparable. La diferencia entre las espumas estriba en la frecuencia para la que la absorción es máxima (Figura 2(b)) y en sus propiedades mecánicas.

Las propiedades mecánicas de los sólidos celulares están fundamentalmente determinadas por su densidad. Algunas de sus propiedades obedecen a una ley del tipo: $A(p)=C \cdot \rho_{n}$ donde $A$ es la magnitud de interés, $C$ es una constante, $\rho$ es la densidad y $n$ es un exponente cuyo valor oscila entre 1,5 y 2 para las espumas de aluminio (14). Este tipo de dependencia ha sido comprobada experimentalmente para magnitudes como la conductividad, resistencia a compresión..... pero fundamentalmente se ha probado su aplicabilidad para el módulo de Young (15-16). Más exactamente, el módulo de Young de los sólidos celulares se relaciona con el del material que constituye su matriz mediante la siguiente expresión [1]:

$$
\frac{E^{*}}{E_{S}}=C \cdot\left(\frac{\rho^{*}}{\rho_{S}}\right)^{n}
$$

siendo $\left(E^{*}, \rho^{*}\right)$ y $\left(E_{S}, \rho_{S}\right)$ el módulo de Young y la densidad del sólido celular y de su matriz respectivamente. En particular, para las espumas de aluminio se consiguen buenos resultados con $C \approx y n \approx 2$ (16). Para estos valores de las constantes y usando $70 \mathrm{GPa}$ y $2700 \mathrm{~kg} / \mathrm{m}^{3}$ para el módulo de Young y para la densidad del aluminio respectivamente para las espumas ALPORAS se obtiene un valor de $E^{*}$ de $1 \mathrm{GPa}$ lo que está de acuerdo con los valores medidos experimentalmente. Por tanto, podemos utilizar la expresión [1] para hacer una primera estimación del módulo de Young de las espumas de aluminio fabricadas. En la Figura 3 se ha representado el valor de $E^{*}$ calculado según la expresión [1] en función de la densidad de la espuma. Dados los valores de $\rho^{*}$ de las muestras fabricadas mediante la técnica pulvimetalúrgica su values in E3 and E4. When these foams were cut into 5and 10- $\mathrm{mm}$ samples, some of the cavities were likewise affected and while they perforated the entire sample, they were shorter or shallower than in the original material. The shorter the channel, the shorter the path travelled by the sound wave inside the material and the lower the friction.

While a detailed study is required to explain the behaviour of the normal incidence absorption coefficient in these foams, certain qualitative conclusions can be drawn from the initial measurements reported here. There are no perceptible differences between the foams attributable to the foaming agent ( $\mathrm{TiH}_{2}$ or marble) used to generate the precursor. Results comparable to ALPORAS foam performance can only be attained if the density of foams made with powder metallurgy technology is lowered by, for instance, increasing the amount of foaming agent in the precursor. For thicknesses under $10 \mathrm{~mm}$, the $\alpha_{M}$ value was similar in all the foams. The difference between foams lay in the frequency at which absorption peaked (Figure 2(b)) and their mechanical properties.

The mechanical properties of cellular solids depend essentially on their density. Some of these properties fit the following type of equations: $A(p)=C \cdot \rho_{n}$ where $A$ is the magnitude sought, $C$ is a constant, $\rho$ is density and $n$ is an exponent whose value ranges from 1.5 to 2 for aluminium foams (14). This type of dependence has been experimentally verified for parameters such as conductivity and compressive strength, but its applicability has been proven primarily for Young's modulus (15-16). More precisely, in cellular solids, Young's modulus is related to the base material as shown in the following expression [1]:

where $\left(E^{*}, \rho^{*}\right)$ and $\left(E_{S}, \rho_{S}\right)$ are Young's modulus and the density of the cellular solid and its constituent material, respectively. Specifically, good results are obtained for aluminium foams with $C \approx 1$ and $n \approx 2$ (16). Using these values for the constants and $70 \mathrm{GPa}$ and $2700 \mathrm{~kg} / \mathrm{m}^{3}$ for Young's modulus and aluminium density, respectively, the $E^{*}$ found for ALPORAS foams was $1 \mathrm{GPa}$, which is consistent with the experimental values. Consequently, expression [1] can be used for an initial estimate of Young's modulus in the aluminium foams prepared for the study. The $E^{*}$ value found with expression [1] is plotted against foam density in Figure 3. Given the values of $\rho^{*}$ for the samples processed with powder metallurgy 


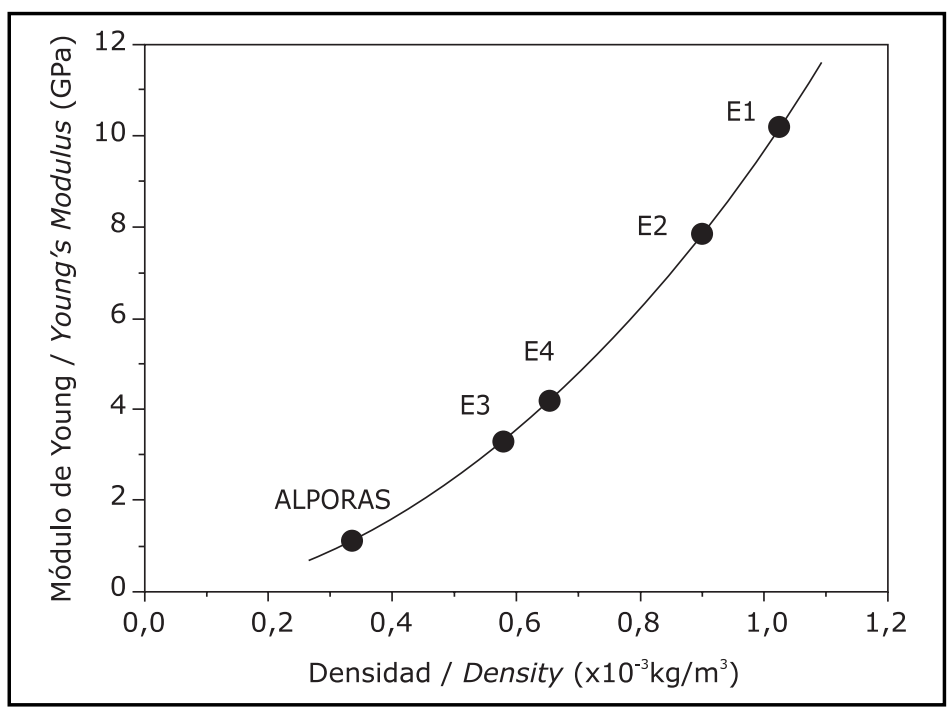

Figura 3. Módulo de Young calculado a partir de la expresión [1] para las espumas de aluminio fabricadas y la comercial ALPORAS.

Figure 3. Young's modulus values found with expression [1] for all the aluminium foams prepared for the study and the ALPORAS commercial product.

valor de $E^{*}$ está lógicamente por encima del de las comerciales ALPORAS.

Además de la absorción del sonido, hay que tener en cuenta otras propiedades o cualidades al seleccionar un material acústico. Entre estas propiedades se incluyen: resistencia al fuego, resistencia mecánica, mantenimiento y limpieza, apariencia, peso....

El cálculo aproximado de $E^{*}$ sirve para mostrar que paneles perforados basados en las espumas de aluminio podrían responder muy bien a estas propiedades ya que en general la mayoría de los materiales acústicos se caracterizan por una resistencia mecánica relativamente baja. Como una primera aproximación a esta posibilidad en los dos apartados siguientes se analiza el coeficiente de absorción acústica a incidencia normal de las espumas fabricadas combinadas con una cámara de aire o con lanas minerales (17). Se han escogido estas dos posibilidades por tratarse de soluciones constructivas habituales para el control del ruido y el tiempo de reverberación en los recintos.

\subsection{Estudio del efecto de una cámara de aire}

Para conseguir un coeficiente de absorción elevado a bajas frecuencias, no es imprescindible hacer uso de materiales muy gruesos. Principalmente en el rango de frecuencias bajas, la absorción del sonido está afectada por la profundidad del espacio, cámara de aire, entre el frente del material acústico y una superficie rígida de apoyo detrás de él. Una cámara de aire detrás de un material poroso aumenta significativamente la absorción technology, their $E^{*}$ value was logically higher than the value for the commercial ALPORAS material.

In addition to sound absorption, other properties or features must be borne in mind when choosing acoustic insulation, including fire resistance, mechanical strength, maintenance and cleaning, appearance, weight...

The approximate calculation of $E^{*}$ shows that aluminium foam-based perforated panels would perform well in all these respects, and better than most acoustic insulation in terms of mechanical strength. As an initial approach to studying the potential benefits, the normal incidence sound absorption coefficient was found for processed foams used in conjunction with an air gap or mineral wool, as discussed in the following two items (17). These two combinations were chosen on the grounds of their standard use as noise and reverberation control solutions in construction.

\subsection{Effect of air gaps}

Very thick materials are not necessarily required to obtain high absorption coefficients for low frequencies. In the low frequency range, sound absorption is primarily affected by the depth of the space or air gap between the acoustic material and the rigid wall generally positioned behind it. An air gap behind porous material significantly enhances low frequency sound absorption. The respective tests were conducted on the materials studied here by 
acústica a bajas frecuencias. Para realizar este tipo de ensayos con nuestras espumas se ha reducido su espesor hasta conseguir que algunos poros o cavidades atraviesen completamente el material consiguiendo una situación similar a la de un panel perforado. Hemos estudiado el efecto de una cámara de aire de 2, 5 y $10 \mathrm{~cm}$ de espesor. En el propio tubo de Kundt se puede simular esta posibilidad tal y como se muestra en la Figura 4. Se ha trabajado principalmente con las espumas de aluminio de 5 y $10 \mathrm{~mm}$ de espesor. reducing the thickness to the point that some pores or cavities were completely open cells, to achieve conditions similar to those prevailing in perforated panels The effect of 2-, 5- and 10-cm air gaps was studied. This possibility can be simulated in a Kundt's tube, as shown in Figure 4. The analysis focused on the 5- and 10- $\mathrm{mm}$ thick aluminium foams.

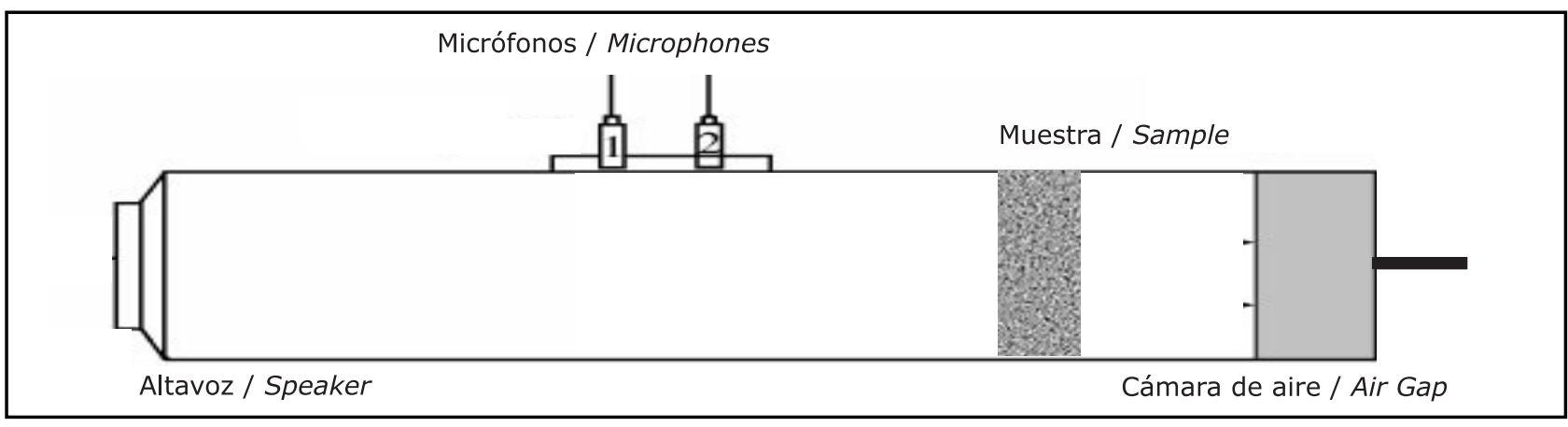

Figura 4. Esquema de la cámara de aire en el tubo de Kundt.

Figure 4. Air gap in the Kundt's tube.

Como ejemplo, en la Figura 5 se muestra el valor de $\alpha_{M}$ para las espumas de aluminio de $5 \mathrm{~mm}$ de espesor en función del espesor de la cámara de aire. No sólo es interesante un desplazamiento del pico de máxima absorción a bajas frecuencias sino el cambio de su anchura. Para cuantificar este efecto, para este máximo del coeficiente
By way of example, the $\alpha_{M}$ value for 5-mm thick aluminium foams is plotted against the air gap thickness in Figure 5. As interesting as the shift to lower frequencies was the change in the width of the absorption peak. To quantify this effect, a quality factor $Q$ was defined for the absorption peak, by analogy to the definition used for

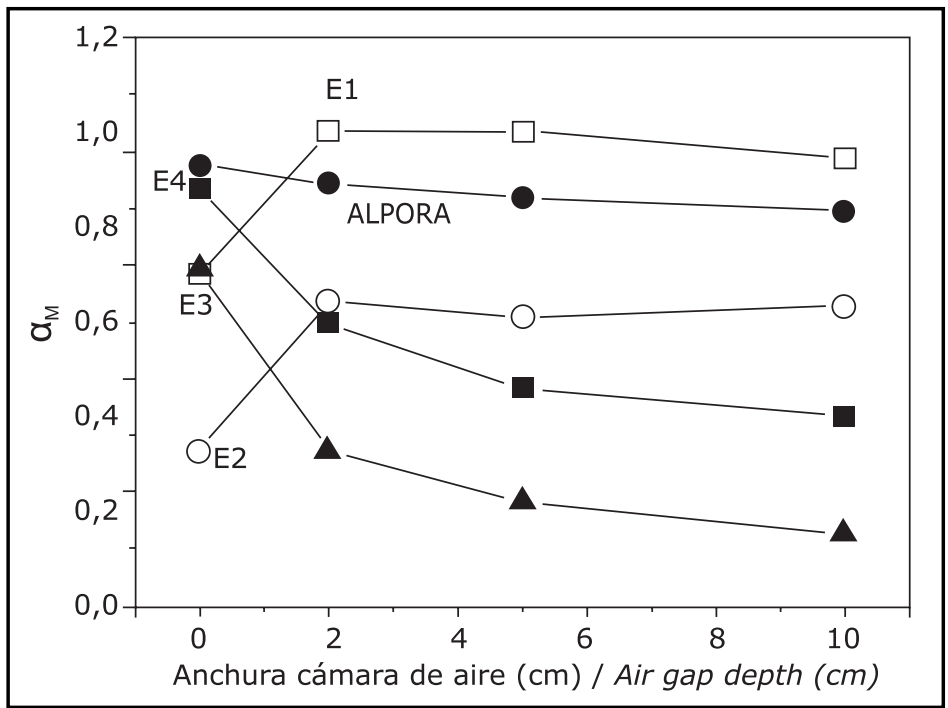

Figura 5. Valor máximo del coeficiente de absorción $\alpha_{M}$ en función de la anchura de la cámara de aire para las espumas de aluminio fabricadas y de $5 \mathrm{~mm}$ de espesor.

Figure 5. Peak absorption coefficient $\alpha_{M}$ versus air gap depth for 5-mm aluminium foams. 
de absorción vamos a definir un factor de calidad $Q$ de manera análoga a como se define para un resonador de Helmholtz (18). En la Figura 6 se muestra para el espesor de $5 \mathrm{~mm}$, fc y Q del máximo de absorción.
Helmholtz resonators (18). The graphs in Figure 6 depict fc and $Q$ for the 5-mm absorption peaks.
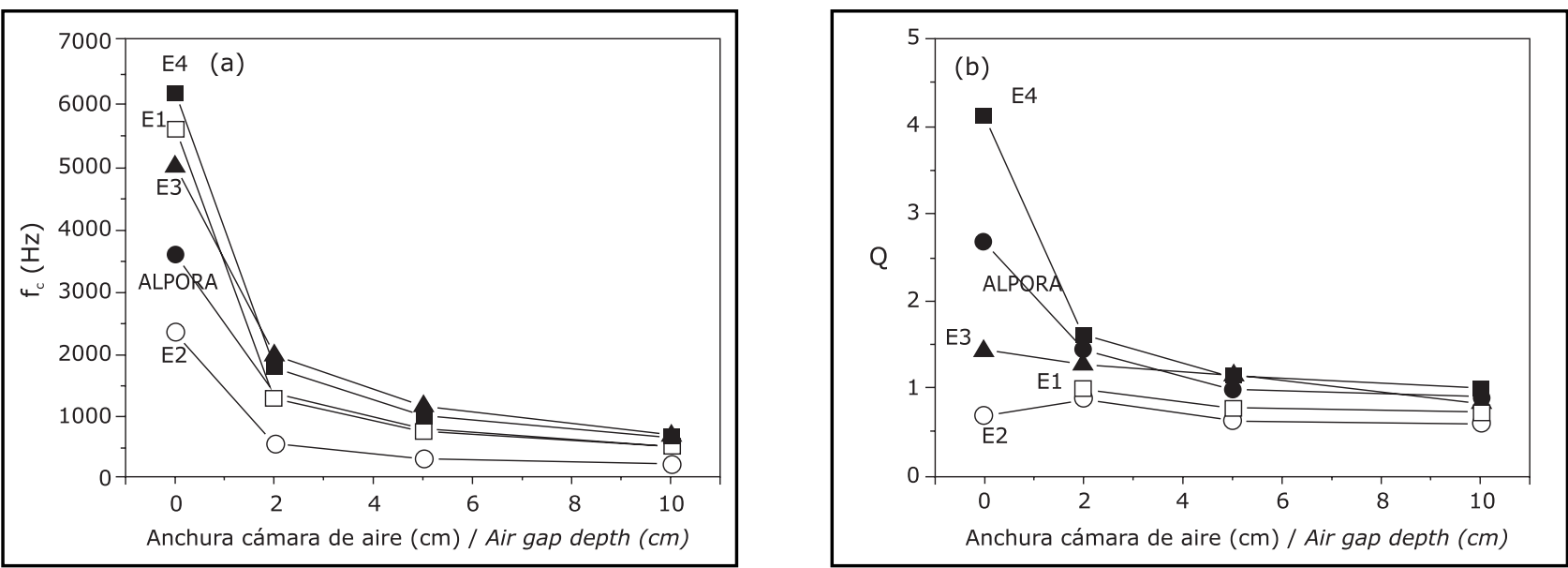

Figura 6. (a) Frecuencia central $f c$ y (b) factor de calidad $Q$ en función de la anchura de la cámara de aire para las espumas de aluminio fabricadas.

Figure 6. (a) Central frequency, $f c$ and (b) quality factor $Q$ versus air gap depth for the aluminium foams prepared for the study.

Para espumas de $5 \mathrm{~mm}$ espesor con cámara de aire los valores más altos de $\alpha_{M}$ corresponden a las espumas E1 y E2 de mayor densidad. En particular, el comportamiento de la espuma E1 es comparable al de la comercial ALPORAS. Para espesores pequeños la fricción es apreciable si el tamaño de la cavidad o poro que atraviesa toda la espuma es pequeño (1-2 mm) como es el caso de las espumas E1 y E2. En las espumas E3 y E4 el tamaño de la cavidad que atraviesa la muestra tiene un diámetro por encima de $5 \mathrm{~mm}$ por lo que la fricción es menor y por tanto el valor de $\alpha_{M}$ disminuye. Hemos comprobado, y se puede deducir de los resultados que se muestran en la Figura 2(a) que para que un comportamiento óptimo de las muestras E3 y E4 como paneles perforados con cámara de aire, esto es para que el valor de $\alpha_{M}$ oscile entre 0,7-0,8, su espesor mínimo debe oscilar entre 8 y $12 \mathrm{~mm}$.

Para todas las espumas se observa el desplazamiento típico a frecuencias menores del máximo de absorción. Desplazamiento tanto mayor cuanto mayor es el espesor de la cámara de aire. Una expresión muy sencilla para determinar la frecuencia a la que la absorción sonora es máxima con cámara de aire es la siguiente:

$$
f_{C}=\frac{60}{\sqrt{m e}}
$$

donde $m$ es la masa del panel por unidad de superficie y es e la profundidad de la cámara de aire (19). Al menos cualitativamente, esta expresión permite explicar que el máximo del coeficiente de absorción sonora para un espesor fijo de la cámara de aire se desplace a frecuen-
The highest $\alpha_{M}$ values for 5-mm foams in the presence of an air gap were found for E1 and E2, the higher density foams. E1 performance, in particular, was comparable to the findings for the commercial foam, ALPORAS. Considerable friction was generated in these thin foams when the cavity or pore perforating the foam was small (1-2 mm), such as in foams E1 and E2. In foams E3 and E4 the size of the open cells in the sample was over $5 \mathrm{~mm}$ in diameter, generating less friction and hence a lower $\alpha_{M}$ value. Pursuant to the results shown in Figure 2(a), to ensure optimum performance in samples E3 and E4 in the presence of an air gap, i.e., to attain an $\alpha_{M}$ value of 0.7 to 0.8 , their minimum thickness must range from 8 to $12 \mathrm{~mm}$.

The characteristic shift in the absorption peak to lower frequencies was observed in all the foams. The deeper the gap, the greater was this shift. A very simple expression for determining the frequency at which air gap-supported sound absorption peaks is:

where $m$ is panel mass per unit of area and $e$ is the depth of the air gap (19). Qualitatively at least, this expression explains why, for a given air gap depth, the lower the aluminium foam density, the lower is the frequency at which sound the absorption coefficient peaks. For foam E2 with 
cias menores para las espumas de aluminio de mayor densidad. Para la espuma E2 con una cámara de aire de $10 \mathrm{~cm}$ de espesor la frecuencia de máxima absorción sonora se sitúa alrededor de los $175 \mathrm{~Hz}$, siendo $Q \approx 0,7$ y $\Delta f \approx 123 \mathrm{~Hz}$, valores interesantes para el control del ruido a baja frecuencia. No se aprecian grandes diferencias entre los valores de $Q$ para las distintas espumas de aluminio fabricadas y la comercial ALPORAS: la anchura del pico de máxima absorción sonora se reduce a medida que aumenta el espesor de la cámara de aire.

\subsection{Estudio de la estructura espuma de aluminio y lana mineral}

Las lanas minerales están constituidas por un entrelazado de filamentos de materiales pétreos que forman un fieltro que mantiene entre ellos aire en estado inmóvil. Esta estructura permite obtener productos muy ligeros que por su peculiar configuración ofrecen elevados niveles de protección frente al calor, el ruido y el fuego. Están reconocidas internacionalmente como absorbentes acústicos y aislantes térmicos. No obstante, presentan una baja resistencia mecánica de modo que es una práctica habitual combinarla con un panel o tablero perforado que aporta una superficie rígida, duradera y de buen aspecto y a su vez puede contribuir a mejorar el comportamiento acústico de la estructura. La rigidez a la estructura podría ser proporcionada por una espuma de aluminio de $5-10 \mathrm{~mm}$ de espesor que actuaría como panel perforado. Por otro lado, la baja corrosión del aluminio podría hacer muy adecuado el uso de estas espumas como paneles en ambientes exteriores.

En este apartado se ha investigado el comportamiento acústico de la combinación espuma metálica y una lana

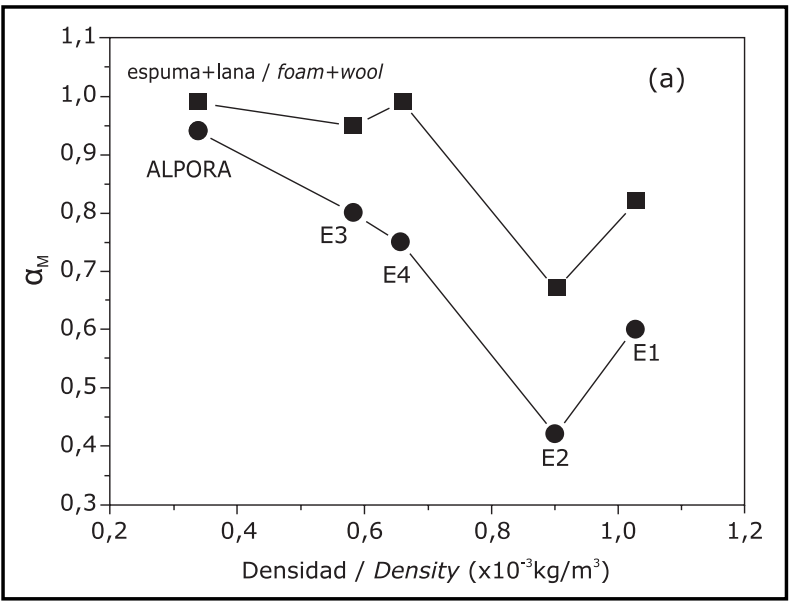

a 10-cm air gap, sound absorption peaked at around 175 $\mathrm{Hz}$, with $Q \approx 0.7$ and $\Delta f \approx 123 \mathrm{~Hz}$, excellent values for low frequency noise control. Large differences were not found between the $Q$ values for the various aluminium foams processed and the ALPORAS market product: the width of the sound absorption peak narrowed with growing air gap depths.

\subsection{Aluminium foam and mineral wool structure}

Mineral wool is made of interlaced stone filaments forming a pad in which immobilized air is trapped. This structural arrangement yields very light weight, fire-resistant and highly effective thermal and acoustic insulation, whose properties are internationally acknowledged. Nonetheless, given the low mechanical strength of these products, they are routinely combined with a perforated panel or board to ensure rigid, long-lasting support and a fine finish that at the same time contributes to enhancing acoustic performance. Five- to ten-mm aluminium foam perforated panels could feasibly be used for this purpose. The high corrosion resistance characteristic of aluminium would, moreover, make such foams particularly suitable in outdoor environments.

In light of the foregoing, the present study included an analysis of the acoustic performance of the combination

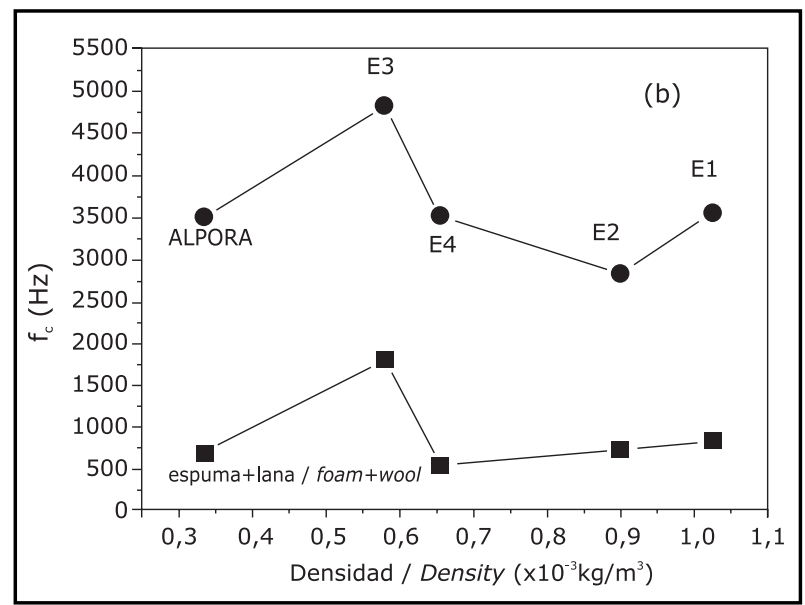

Figura 7. (a) $\alpha_{M}$ y (b) $f c$ del máximo de absorción de las espumas de aluminio fabricadas y de la comercial ALPORAS y de estas mismas espumas con una lámina de $2 \mathrm{~cm}$ de lana mineral. El espesor de las espumas E1 y E2 es de $5 \mathrm{~mm}$ y de las espumas E3 y E4 es de $10 \mathrm{~mm}$.

Figure 7. (a) $\alpha_{M}$ and (b) fc at peak absorption for the aluminium foams studied and the commercial product (ALPORAS) and for all the foams with a 2-cm mineral wool panel. E1, E2 and ALPORAS foam thickness $=5 \mathrm{~mm}$ and $E 3$ and $E 4$ thickness $=10 \mathrm{~mm}$. 
mineral de $2 \mathrm{~cm}$ de espesor. Igualmente se ha estudiado el efecto de una cámara de aire en dos posiciones diferentes: a continuación de la lana mineral y entre la espuma de aluminio y la lana mineral. Las medidas realizadas indican que el principal efecto de la lana mineral es aumentar el valor de $\alpha_{M}$ respecto al valor de la espuma de aluminio y desplazar $f c$ de este máximo a frecuencias inferiores. En la Figura 7 se ha representado $\alpha_{M}$ para las espumas de aluminio y el medido para la estructura espuma de aluminio y lana mineral. Para las espumas E1 y E2 hemos trabajado con muestras de $5 \mathrm{~mm}$ de espesor mientras que en el caso de las espumas E3 y E4 las condiciones más favorables corresponden a un espesor de $10 \mathrm{~mm}$.

Sin embargo, si en la estructura espuma de aluminio y lana mineral incluimos una cámara de aire a continuación de la lana mineral o entre ambos materiales no hay cambios significativos respecto al caso ya estudiado de solo la espuma de aluminio y una cámara de aire. En la Figura 8 se com- of metallic foam and 2-cm thick mineral wool. The effect of an air gap in two different positions was likewise explored: adjacent to the mineral wool side of the structure and between the aluminium foam and the mineral wool. The measurements taken showed that the main effects of the mineral wool were to raise the $\alpha_{M}$ value compared to the values recorded for the aluminium foam and shift the fc for this peak to lower frequencies. Figure 7 shows the $\alpha_{M}$ for the aluminium foams and the value recorded for the aluminium foam plus mineral wool structure. Five-mm samples were used with foams E1 and E2, whereas for foams E3 and E4 the most favourable conditions were found for $10-\mathrm{mm}$ panels.

When the structure was positioned adjacent to an air gap on the mineral wool side or when a gap was set in between the two materials, however, no significant changes were found with respect to the aluminium foam plus air gap arrangement. Figure 8 compares the $\alpha_{M}$, fc and $Q$
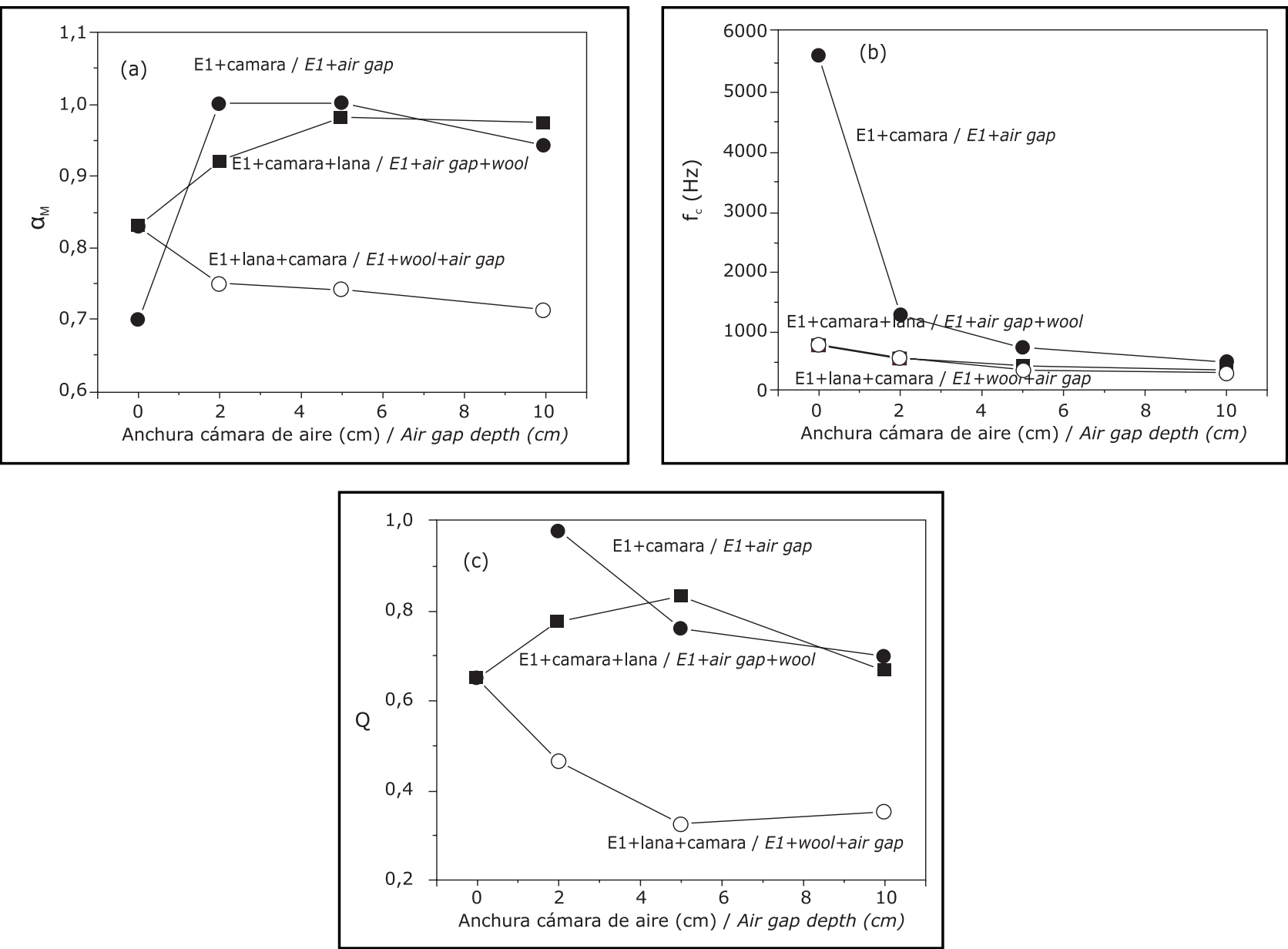

Figura 8. (a) $\alpha_{M}$, (b) $f c y$ (c) factor de calidad $Q$ en función de la anchura de la cámara de aire para la espuma E1 y la misma espuma combinada con una lana mineral. Para la espuma E1 combinada con la lana mineral la cámara de aire se ha situado al final y entre ambos materiales.

Figure 8. (a) $\alpha_{M}$, (b) fc and (c) quality factor $Q$ versus air gap depth in foam $E 1$ and in foam $E 1$ in conjunction with mineral wool, with the air gap adjacent to the mineral wool side and in between the two materials. 
paran el valor de $\alpha_{M}$, fc y de $Q$ del máximo de absorción para la espuma E1 montada según las tres estructuras ensayadas: E1 y cámara de aire; E1, lana mineral y cámara de aire y $E 1$, cámara de aire y lana mineral. Incluida la cámara de aire la primera y tercera estructura son las que presentan un comportamiento más similar. El caso más desfavorable corresponde a la estructura espuma de aluminio, lana mineral y cámara de aire.

\section{CONCLUSIONES}

Se ha presentado un estudio del coeficiente de absorción acústica a incidencia normal en función del espesor de espumas de aluminio fabricadas mediante la técnica pulvimetalúrgica. Se han fabricado espumas variando el agente espumante: $\mathrm{TiH}_{2}$ o mármol y con materiales de relleno. Se ha realizado un análisis comparativo con las espumas de aluminio comerciales conocidas como ALPORAS. Para espesores por encima de $20 \mathrm{~mm}$ sólo las espumas de menor densidad presentan un comportamiento comparable al de las espumas comerciales. No obstante, un valor más elevado de la densidad se traduce en unas mejores propiedades mecánicas.

No existen diferencias apreciables en el coeficiente de absorción acústica máximo entre las espumas fabricadas mediante la técnica pulvimetalúrgica frente a las espumas ALPORAS si se combinan con una cámara de aire. Para este ensayo se han escogido espumas de aluminio de 5 y $10 \mathrm{~mm}$ de espesor para el que algunas de las cavidades atraviesan completamente el material. Estos primeros resultados apuntan a que estas espumas podrían utilizarse como paneles perforados debido a su resistencia mecánica sobre todo en ambientes adversos debido a la baja corrosión y la facilidad de limpieza del aluminio. En recintos cerrados, además de para el control del tiempo de reverberación pueden ser interesantes como elemento decorativo por su aspecto, diferente del de los paneles perforados habituales.

También se han combinado estas espumas de aluminio con lanas minerales. Los resultados indican que el efecto de la lana mineral sobre la espuma de aluminio es un incremento del valor del coeficiente de absorción acústica máximo y un desplazamiento de este pico a frecuencias inferiores. Parece que no es imprescindible incluir la lana mineral si la estructura es una espuma de aluminio y una cámara de aire. Para llegar a esta conclusión se han estudiado las dos combinaciones posibles: espuma de aluminio, lana mineral y cámara de aire; espuma de aluminio, cámara de aire y lana mineral.

Estos primeros experimentos han servido para mostrar que estas espumas de aluminio podrían ser usadas como paneles absorbentes acústicos. No obstante, sobre todo values for foam E1 in the three set-ups tested: E1 and air gap, E1, mineral wool and air gap and E1, air gap and mineral wool. The performance figures for the first and third arrangements were the most similar. The lowest performance was recorded for the aluminium foam, mineral wool and air gap structure.

\section{CONCLUSIONS}

The article discusses the effect of foam thickness on the normal incidence sound absorption coefficient of aluminium foam manufactured with powder metallurgy technology. Foams were prepared with different foaming agents ( $\mathrm{TiH}_{2}$ or marble) and filler materials. These materials were tested against well-known commercial aluminium foams such as ALPORAS. In foams over $20 \mathrm{~mm}$ thick, only the lower density products exhibited performance comparable to commercial foams. That notwithstanding, higher density translated into enhanced mechanical strength.

No perceptible differences were found in the sound absorption coefficient peak between the aluminium foams processed with powder metallurgy technology and the ALPORAS foam when the materials were used in conjunction with an air gap. Five- and $10-\mathrm{mm}$ thick foams were chosen for this test to ensure that some of the cavities in the material were completely open cells. The initial results reported here indicate that their mechanical strength, high corrosion resistance and easy cleaning and maintenance make these foams particularly suitable for adverse environments. Indoors, in addition to controlling the reverberation period, they can be used as decorative elements, for they are more aesthetically acceptable than standard perforated panels.

These aluminium foams were also tested in combination with mineral wools. The results showed that combining aluminium foam with mineral wool raised the value of the sound absorption coefficient peak and shifted this peak to lower frequencies. Mineral wool would not appear to be indispensable when aluminium foam is used in conjunction with an air gap. The two possible combinations studied to reach this conclusion were: aluminium foam, mineral wool and air gap; and aluminium foam, air gap and mineral wool.

These initial experiments served to show that aluminium foams can be used as sound absorbent panels. Nonetheless, in particular for a more accurate study of low 
para un estudio más exacto de las bajas frecuencias el siguiente paso es fabricar estas espumas con un diámetro de $100 \mathrm{~mm}$ para realizar los ensayos en la configuración de bajas frecuencias del tubo de Kundt. frequencies, the next step is to make $100-\mathrm{mm}$ diameter foams to conduct low frequency tests in a Kundt's tube.

\section{BIBLIOGRAFÍA / BIBLIOGRAPHY}

(1) Banhart, J.: "Manufacture, characterisation and application of cellular metals and metal foams", Progress in Materials Science, vol. 46 (2001), pp. 559-632. http://dx.doi.org/10.1016/S0079-6425(00)00002-5

(2) Baumeister, J., Banhart, J. and Weber, M.: "Aluminium foams for transport industry", Materials and Design, vol. 18 (1997), pp. $217-220$. http://dx.doi.org/10.1016/S0261-3069(97)00050-2

(3) Banhart, J. and Weaire, D.: "On the road again: metal foams find favour", Physics Today, (2002), pp. 37-42. http://dx.doi.org/ $10.1063 / 1.1506749$

(4) Lu, T. J. , Hess, A. and Ashby, M. F.: "Sound absorption in metallic foams", Journal of Applied Physics, vol. 85 (1999), pp. $7528-7539$.

(5) Allard, J. F., Propagation of sound in porous media, Elsevier Science Publishers, Inglaterra 1993.

(6) Umnova, O., Attenborough, K., Sin, H. and Cummings, A.: "Deduction of tortuosity and porosity from acoustic reflection and transmission measurements on thick samples of rigid-porous materials", Applied Acoustics, vol. 66 (2006), pp. 607-624. http://dx.doi.org/ 10.1016/j.apacoust.2004.02.005

(7) García Cambronero, L. E., Pozas, A., Ruiz Román, J. M. and Suarez, J. C.: "Efecto del tamaño de partícula del TiH2 en el comportamiento a compresión de espumas de AA6061+10SiC", XI Congreso Nacional de Materiales, 20-23 de Junio (Vigo, 2006), pp. 847-850.

(8) García Cambronero, L. E., Ruiz Román, J. M., Cañadas, I. and Martínez, D.: "Características de la estructura celular en espumas de Al-7Si con mármol obtenidas mediante energía solar concentrada", XI Congreso Nacional de Materiales, 20-23 de Junio (Vigo, 2006), pp. (9) Baumeister, J.: US Patent 5151246, 1992.

(10) Seybert, A. F. and Ross, D. F.: "Experimental determination of acoustic properties using a two-microphone randomexcitation technique", Journal of Acoustics of American Society, vol. 68 (1980), pp. 1362-1369.

(11) ISO 10534-2: 1998, Acoustics determination of sound absorption coefficient and impedance or admittance by the impedance tube. Part II: Transfer function method.

(12) Bodén, H. and Abom, M.: "Influence of errors on the two-microphone method for measuring acoustics properties in ducts", Journal of Acoustics of American Society, vol. 79 (1986).

(13) Seybert, A. F. and Soenarko, B.: "Error analysis of spectral estimates with application to the measurement of acoustic parameters using random sound fields in ducts", Journal of Acoustics of American Society, vol. 69 (1981), pp. 1190-1199. http://dx.doi.org/10.1121/ 1.385700

(14) Gibson, L. J. and Ashby, M.: Cellular Solids: structure and properties, $2^{\circ}$ edition, Solid State Science, Cambridge University Press, UK (1997).

(15) Liu, Z. and Scanlon, M. G.: "Scaling Young's modulus of cellular solids", Journal of Materials Science Letters, vol. 22 (2003), pp. 547-548. http://dx.doi.org/10.1023/A:1022950706432

(16) Tuner, E. and Wegener, W., "Elastic properties of highly anisotropic thin poly(propylene) foam", submitted to Elseiver Science.

(17) Sgard, F. C., Olny, X., Atalla, N. and Castel, F.: "On the use of perforations to improve the sound absorption of porous maerials", Applied Acoustics, vol. 66 (2005), pp. 625-651. http://dx.doi.org/10.1016/j.apacoust.2004.09.008

(18) Kinsler, L. E., Fret, A. R., Coppens, A. B. and Sanders, J. V.: "Fundamentos de acústica", Ed. Limusa, 1995.

(19) Díaz Sanchidrián, C.: "Apuntes de acústica en la edificación y el urbanismo", Cuaderno 51 del Instituto Juan de Herrera de la Escuela de Arquitectura de Madrid. 